\title{
The Role of Visum Et Repertum as A Provision Effort On Criminal Financing
}

\author{
Lilik Eko Sukaryono ${ }^{1}$ and Amin Purnawan ${ }^{2}$
}

\begin{abstract}
In the process of investigating criminal cases of persecution relating to the body, health, and human lives, it requires the assistance of a medical expert. The assistance of a doctor with his medical science of justice as stated in the Visum et repertum which he made is absolutely necessary. The formulation of the problem that was formed in this study is how the role of visum et repertum as evidence in the implementation of court cases of persecution in the Blora State Court, and what obstacles and solutions that occur in the form of evidence visum et repertum in cases of criminal abuse. Juridical sociology as an approach method used in this study with research specifications with descriptive methods. The data used consisted of primary data and secondary data using interview and literature study methods. Based on the research it was concluded (1) The role of Visum et repertum in the case of mistreatment in case decision number 184 / Pid.B / 2018 / PN Bla, the judge weighed on the elements in Article 351 paragraph 1 of the Criminal Code in which the result was a feeling of discomfort, pain or injury, which is based on evidence in the form of Visum et repertum on the victim's body. (2)Obstacles in proving in the form of visum et repertum in cases of torture include the qualification of wounds based on the legal needs confusing a doctor, standardization of the determination of the degree of injury to be poured on the Visum et repertum, Provisions for the signing of the post visum et repertum letter by the doctor, Request for visum et repertum which is lacking / incomplete, Visum Request Letter arrives late.

Keywords: Visum Et Repertum; Evidence; Criminal Acts Of Persecution.
\end{abstract}

\section{Introduction}

In criminal law contains rules about public life that are made in material terms, namely regulating the legal relationship between citizens and the state. Therefore, in resolving various criminal acts that occur, formal criminal law or criminal procedural law is needed, which will determine who is wrong and who is right. Criminal Procedure Law in Indonesia is regulated in Act No. 8 of 1981 known as the Criminal Procedure Code (KUHAP). The purpose of criminal procedure law is to seek and obtain or at least approach material truth, that is, the complete truth of a criminal case by applying the provisions of the criminal procedure law honestly and precisely, with the aim of finding out who the perpetrators can be charged with violating the law, and then requests an examination and decision from the court to determine whether it is proven that the crime has been committed and whether the accused

\footnotetext{
${ }^{1}$ Student of Master of Law, Universitas Islam Sultan Agung Semarang and Indonesian Police, email: liliksukaryono@gmail.com

${ }^{2}$ Lecturer of Faculty of Law, Sultan Agung Islamic University (UNISSULA), Semarang
} 
person can be blamed. To determine whether or not a defendant has committed an act committed against him, then a evidence is needed. Evidenceing is the provisions containing inheritance and guidelines on the methods that are justified by the law to prove the guilt of the accused. ${ }^{3}$

In criminal procedural law, evidence is a central point as well as to search for material truth, that is the truth that is actually. In the trial process the defendant can be said to have violated the law or is guilty if it can be proven with evidence that is valid according to the law that has been determined and with the conviction of a judge obtained or arisen from evidence that is valid according to the law. If in the evidence, the evidences determined by the law are not sufficient to prove the defendant's guilt, then the defendant is acquitted, but if the defendant's guilt can be proven according to the evidence, the defendant must be convicted and a criminal sentence must be handed down. To determine the defendant is truly guilty, the required evidence must be more than one or at least two legal evidences according to the law. This can be seen in Article 183 of the Criminal Procedure Code which reads:

"A judge cannot convict a person unless if with at least two legal pieces of evidence he gains the conviction that a crime has actually taken place and that the defendant is guilty of committing it."

The rise of the persecution that we see from various sources is a sign that it cannot be separated from the poorly controlled behavior of the people, which is due to the low level of education and the influence of a bad social environment. Personal or group disputes can be a factor that can lead to violence that results in persecution.

Criminal provisions against criminal acts or offenses themselves have been contained in the Criminal Code, namely Article 351 to Article 358 of the Criminal Code which confirms that:

(1) Persecution is punishable by imprisonment of up to two years and eight months or a maximum fine of four thousand five hundred rupiahs; (2) If the act causes serious injuries, the guilty person is threatened with a prison sentence of no more than five years; (3) If they result in death, they are liable to a maximum of seven years imprisonment; (4) Equated with deliberate intentionally damaging health; and (5) Attempts to commit this crime were not convicted.

In the investigation stage also has an important role to help investigators find and gather evidence in an effort to provide material truths of a criminal case. The regulation of legal evidence is regulated in Act No. 8 of 1981 concerning the Criminal Procedure Code (KUHAP) in Article 184 paragraph (1) which explains legal evidence in the form of witness statements, expert statements, letters, instructions, statements of the defendant. ${ }^{4}$ In the process of investigating criminal cases relating to the body, health, and human lives requires the assistance of a medical expert. The assistance of a doctor with his medical science of justice as stated in the Visum et repertum which he made is absolutely necessary. Visum et repertum as a written report for the benefit of the judiciary at the request of law enforcement authorities here specifically

\footnotetext{
${ }^{3}$ M. Yahya Harahap, 2002, Pembahasan Permasalahan dan Penerapan KUHAP, Jakarta: Sinar Grafika, p. 273

${ }^{4}$ Article 184 paragraph (1) of Act No. 8 of 1981 concerning KUHAP
} 
by the investigator. Visum et repertum is made by doctors according to what they see and find in the examination of evidence, based on medical oaths, and based on their knowledge. ${ }^{5}$

In connection with the role of Visum et repertum in revealing a case of persecution, therefore, the authors are interested in further researching and pouring it in legal research with the title: "Role of Visum et repertum as Evidence of Effort During the Criminal Offense (Case study In Blora State Court) ".

Based on this background, the researchers took the formulation of the problem including the following two things: What is the role of visum et repertum as evidence in the execution of cases of torture in the Blora State Court?; What are the obstacles and solutions that occur in the form of visum et repertum in the case of torture?

\section{Research methods}

To conduct a study in this study the writer uses the sociological juridical method (social legal research) to study and discuss the problems raised. Juridical is an approach that uses the principles and legal principles derived from written regulations, sociological is an approach that aims to clarify the actual conditions that exist and appear in society to the problem under study. ${ }^{6}$ This study uses research specifications with descriptive methods. The data used for this study are primary and secondary data. To obtain data in this study, data collection methods such as interviews and literature study were used.

\section{Results and Discussion}

\subsection{The Role Of Visum Et Repertum As Evidence In The Implementation Of Judicial Cases Of Persecution In The Blora State Court}

In the mechanism of the role of Visum et repertum as evidence in the implementation of court cases of persecution based on the results of the author's research in the Blora State Court in the form of a case decision Number 184 / Pid.B / 2018 / PN Bla, which explains the legal facts in the form of:

That Defendant Sarnata bin Parjan on Wednesday, August 15, 2018, was around 16:30 WIB in the house of Br. Lumadi Dk.Ngawenan rt.04 rw.04 Sambongrejo Village, Sambong Regency of Blora or at least in a place that is still within the jurisdiction of the Blora State Court, commits torture. These acts were carried out by the Defendant in the following manner: ${ }^{7}$

Starting on Wednesday, August 15, 2018 at 11:00 AM the Defendant and his friends included witness Yatno alias Mr.Osi gathered at the Lumadi witness house located in Jepon Village, Blora then in the middle of chatting with each other mocked between

\footnotetext{
${ }^{5}$ Soeparmono, 2016, Keterangan Ahli \& Visum et Repertum dalam Aspek Hukum Acara Pidana, Bandung: CV. Mandar Maju, p.75.

${ }^{6}$ Rony Hanitijo Soemitro, 1990, Metodologi Penelitian Hukum dan Jurimetri, Jakarta: Ghalia Indonesia, p.34

${ }^{7}$ Decision on Case Number 184 / Pid.B / 2018 / PN Bla
} 
the Defendant and witness Yatno who made the Defendant hurt and went home and took a knife or bayonet from his house, but when the Defendant had taken the bayonet knife and was about to attack Yatno's witness,

That based on the results of Visum et repertum wound Number: 440/153 / VIII / 2018, dated August 23, 2018, issued by the Sambong Health Center signed by dr.Dhania Jayantika Suparno concluded that there was a torn wound on the right upper hand, upper right chest and bruises in the mouth due to sharp weapons and these wounds hinder daily activities. Acts of the Defendant as regulated and threatened with crime in Article 351 paragraph (1) of the Criminal Code. ${ }^{8}$ In this case the judge considered, the Public Prosecutor had submitted evidence in the form of 1 (one) sharp weapon in the form of a $30 \mathrm{~cm}$ long knife or sakur made of iron and that the trial of the Public Prosecutor had also read the results of the Visum et repertum from the Sambong Health Center signed by Dr. Dhania Jayantika Suparno, who concluded that there was a torn wound in the upper right hand, upper right chest and bruises in the mouth due to a sharp weapon which was the result of Visum et repertum as evidence of the letter in the case of the persecution. ${ }^{9}$

In an effort to prove through Visum et repertum, based on the results of interviews with Blora State Court judges namely Makmurin Kusumastuti, Visum et repertum is one of the evidences included in the category of evidence at the stage of criminal justice in the investigation process, which is requested by the investigator to the doctor / medical to explain one's injury / injury / time of death for the purposes of investigation. He also explained the procedure for making a visum et repertum in the examination of criminal acts. The stages are:

- The first stage of the investigator underlies the police report about the alleged crime;

- The second stage looks at the results of the examination of the victim about what she suffered according to the report that is attached in the police report;

- The third stage the investigator submits a written request to the doctor regarding the request to be made a visum et repertum;

- The fourth stage the investigator then requests the results of the post mortem visum et repertum which has been requested to make the visum et repertum. ${ }^{10}$

From interviews with informants Makmurin Kusumastuti also explained how visum et repertum was considered valid and accepted as evidence of the letter. Visum et repertum is considered valid and accepted as evidence of a letter if issued by government doctors or hospitals and made in formal service. And investigators from the Police Department do not have restrictions to determine whether the visum et repertum is valid as evidence for a letter. ${ }^{11}$

\footnotetext{
${ }^{8}$ Decision on Case Number 184 / Pid.B / 2018 / PN Bla

${ }^{9}$ Decision on Case Number 184 / Pid.B / 2018 / PN Bla

${ }^{10}$ Research Results in the Form of Interviews with Makmurin Kusumastuti, $\mathrm{SH}, \mathrm{MH}$, Judge of the Blora State Court, Held on December 10, 2019.

${ }^{11}$ Research Results in the Form of Interview with Makmurin Kusumastuti, SH, MH, Judge of the Blora State Court, Held on December 10, 2019
} 
Visum et repertumin its role in the judge's decision in case number 184 / Pid.B / 2018 / PN Bla as a form of implementing the rule of law to achieve legal certainty. Based on the theory of Kelsen's theory of legal certainty, law is a norm system. Norms are statements that emphasize the "should" or das sollen aspects, including some rules about what should be done. Norms are deliberative human products and actions. Laws that contain general rules are guidelines for individuals behaving in society, both in relationships with individuals and in relations with the community. The rules become a limit for society in burdening or taking action against individuals. ${ }^{12}$

\section{Obstacles and Solutions That Occur In Evidence in the Form of Visum Et Repertum In The Case Of Persecution}

The implications of this study indicate a relationship between the existence, Visum et repertum with the judge's decision. The function of the Visum et repertum is as one of the legal pieces of evidence related to criminal acts of persecution (KUHAP Article 184). Visum et repertum bridges the truth of the silence of the human body with the law. ${ }^{13}$ Qualification of minor, moderate and severe injuries can be identified through the conclusions section of the Visum et repertum which is revealed by doctors as being considered an expert in the medical field.

Provisions on doctor assistance for judicial purposes in the Criminal Procedure Code are listed in Articles 133 and 179 and 180. If a doctor is asked to provide visum et repertum, the doctor is legally obliged to do so and there is no reason to refuse. ${ }^{14}$ Patients included in the scope of clinical forensic services are patients who come with a request for a post mortem, a patient who is a victim of a criminal offense.

The results of an interview with Makmurin Kusumastuti, judge of the Blora State Court, which became an obstacle in the evidence of visum et repertum in criminal cases of persecution and with solutions to overcome these obstacles include: ${ }^{15}$

- Qualifying wounds based on confusing legal needs for a doctor;

Qualification of wounds based on legal requirements is also often a confusing matter for a doctor, especially for minor and moderate injuries. The uncertainty of a doctor's opinion as a basis for decision making can be an unfavorable decision in the judicial process. This shows that the existence of Visum et repertum as legal evidence must also be balanced with the quality of Visum et repertum as well. So far there has been no research on the quality of Visum et repertum in the Blora Residency area.

- Standardization of the determination of the degree of injury to be poured on the Visum et repertum

\footnotetext{
12 Peter Mahmud Marzuki, 2008, Pengantar Ilmu Hukum, Kencana, Jakarta: Kencana

${ }^{13}$ D. Afandi, 2009, Visum et Repertum pada Korban Hidup, Jurnal IImu Kedokteran, Vol.3 paragraph II, p.79-84.

${ }^{14}$ B Sampurna, Z Syamsu, Siswaja, 2008, Peranan IImu Forensik Dalam Penegakan Hukum, Jakarta: Forensic Medicine, University of Indonesia, p.61

${ }^{15}$ Research Results in the Form of Interview with Makmurin Kusumastuti, $\mathrm{SH}, \mathrm{MH}$, Judge of the Blora State Court, Held on December 10, 2019
} 
In the conclusion section, problems often occur in determining the degree of injury. The degree of injury is closely related to the type of abuse committed and the severity of the threat of punishment against the perpetrator. In general, the determination of the degree of injury is not difficult for doctors, but until now there is no standardization of the determination of the degree of injury, doctors will only make the degree of injury based on their respective thoughts, so that the degree of injury can be different from one doctor to another doctor. But in this case as long as what is made by doctors can be accounted for scientifically and the need for increased standardization in the form of regulations on visum et repertum letters is important to be delegated to the legal process so confusion in the judge's judgment with evidence in the form of visum et repertum does not occur.

- Provisions on the signing of the post mortem et repertum letter by the doctor The signing of the post mortem is carried out by the examining doctor. If there is only one doctor examining the victim, signing is not a problem. Problems will arise if, the victim is handled by several doctors, for cases like this there is no provision about who should sign, can the doctor in the Emergency Department (IGD) or the treating doctor or all doctors involved. Provisions on who must sign must be agreed by the respective hospital and health center so that there is no valid error in the visum et repertum when it is presented as evidence at the trial of the persecution case.

- Request for a deficient / incomplete post mortem

From the facts so far, often requests for visas from the authorities when investigated are incomplete or incomplete, sometimes there is no number, date or complete information about the victim, not even signed. This requires the coordination between law enforcement officers and medical personnel who will conduct visum et repertum and the need to improve the quality of understanding of the formality of the post mortem visum required for the trial requirements to be made in detail and detail in the editors as the validity of the evidence of evidence for the elements of action criminal maltreatment.

- Visum Request Letter (SPV) arrives late

The new doctor will issue a post mortem report if there is a written request from the investigator in the form of a post mortem request (SPV). In daily practice SPV often comes later. For some this is understandable, perhaps on the grounds of the condition of the victim which makes it impossible to report to the police, the distant police station or do not understand the procedures for reporting to the police. So that what often happens is the victim of a criminal offense with a request for a post mortem that arrives late, the doctor has difficulty making a post mortem because the wound has been treated and no longer remembers the description of the wound the first time the patient arrived, so the evidence becomes non-genuine / lost. In relation to this obstacle,

\section{Closing}

\subsection{Conclusions}


- The role of Visum et repertum in the case of persecution in case number 184 / Pid.B / 2018 / PN Bla in which the judge considers the elements in Chapter XX concerning Persecution Article 351 paragraph (1) of the Criminal Code in which the element is carrying out the persecution that the consequences in this case in this case is feeling unwell, pain or injury, which is based on evidence in the form of Visum et repertum on the victim's body. The strength of evidence visum et repertum is a perfect evidence of what is contained therein so the conclusions or opinions of the doctors put forward therein must be trusted as long as there is no other evidence that weakens;

- Obstacles in proving in the form of visum et repertum in cases of torture and with solutions to overcome these obstacles include qualification of wounds based on confusing legal needs for a doctor, standardization of the determination of the degree of injury to be poured on the Visum et repertum, Provisions for signing the post mortem et repertum by a doctor, Request for visum et repertum that is incomplete / incomplete, Visum Request Letter (SPV) arrives late.

\subsection{Suggestions}

- Although in the Criminal Procedure Code, there is no requirement for investigators to submit requests for Visum et repertum to judicial medical experts or other doctors (experts), but for the purpose of examining the case and to be more clear on the case wherever possible, whenever a request is made to a non-expert doctor then the request is deserved;

- Expert doctors or non-experts in conducting examinations of victims of crime must act objectively according to the oath of doctor's position;

- For the government, it is necessary to facilitate a special space for victims of torture and other crimes that require the role of visum et repertum in every health service from the hospital level to launch the process of making a visum et repertum as a manifestation of the operation of criminal law that results in a legal certainty. .

\section{References}

\section{Books}

[1] B Sampurna, Z Syamsu, Siswaja, 2008, Peranan Ilmu Forensik Dalam Penegakan Hukum, Jakarta: Forensic Medicine, University of Indonesia

[2] M. Yahya Harahap, 2002, Pembahasan Permasalahan dan Penerapan KUHAP, Jakarta: Sinar Grafika

[3] Peter Mahmud Marzuki, 2008, Pengantar Ilmu Hukum, Jakarta: Kencana

[4] Rony Hanitijo Soemitro, 1990, Metodologi Penelitian Hukum dan Jurimetri, Jakarta: Ghalia Indonesia

[5] Soeparmono, 2016, Keterangan Ahli \& Visum et repertum dalam Aspek Hukum Acara Pidana, Bandung: CV. Mandar Maju

\section{Regulations}

[1] The 1945 Constitution of the Republic of Indonesia 
Jurnal Daulat Hukum: Volume 3 Issue 1, March 2020: 131 - 138

[2] Criminal Law Book

[3] Criminal Procedure Code

\section{Journals and Documents}

[1] D. Afandi, Visum et repertum pada Korban Hidup, Journal of Medical Sciences, Vol.3 paragraph II, 2009

[2] Decision on Case Number 184 / Pid.B / 2018 / PN Bla 